\title{
SAILING AGAINST THE TIDES: A FEMINIST, POST- COLONIAL READING OF AMA ATA AIDOO'S NO SWEETNESS HERE
}

\author{
Dr. Abeer Mostafa Elgamal \\ Lecturer of English language and literature \\ Department of Foreign Languages \\ Faculty of Education, Mansoura University
}

One Day!

One day, we shall explode the negative silences and paralyz-

ing terror imposed upon us by tyranny of dominat-

ing cultures and their languages of conquest. We shall

discover the authentic voices of our selfnaming and re-

naming, reclaiming our role as composers, speaking for

ourselves, because we too have tongues, you know!

One day! (Mugo 1994, 84-85)

In her writing, Ama Ata Aidoo (1942- ) challenges all forms of hierarchy both colonial and patriarchal, traditional and contemporary. What she writes, whether fiction or nonfiction is defined by who she is: an African woman writer. Like most post-colonial African literature hers is characterized by challenging imperial hegemony and repressive neocolonial governments. She lashes with criticism patriarchal dominance, especially African male critics who ignore of belittle female writers. Moreover, she defies literary establishments for treating postcolonial literature as second-class or subsidiary to western literature as well as white feminist who allocate an inferior position for African women generally and women writers in particular. In a word, she goes against all tides. This study attempts a feminist, post-colonial reading of Aidoo's collection of short stories No Sweetness
Here. Like most of her poetry and plays, the stories reflect her belief in a distinct African identity, her faith in the strength of African women, and her resistance of hegemony in all its shapes.

According to Bill Ashcroft, there is a huge discrepancy between the reality of colonization and the image colonial discourse propagates about it:

The huge contradiction of empire...(is clear in its) geographical expansion, designed to increase the prestige and economic or political power of the imperial nation, and its professed moral justification, its 'civilizing mission' to bring order and civilization to the barbarous hordes...the simple fact remains that these colonized peoples, cultures and ultimately nations were prevented from becoming what they might have become: they were never allowed to develop into the societies they might have been. (1)

As a post-colonial writer, Aidoo attempts to reclaim the cultural identity of her people and write back to the colonizer using his/her own language. To use William Luis's words, "The Slave, Caliban, uses Prospero's imposed language to undermine the master's powers" (250). The paper addresses the problematic conflict that might come to mind while 
reading Aidoo's work: while challenging one hierarchy, can Aidoo be supporting another? To put the question more accurately, does Aidoo's feminist challenge to traditional patriarchy undermine her Afrocentric challenges to Eurocentric hegemony? Is her critique of colonialist racism weakened by her critique of patriarchal sexism? The study proposes that she skillfully manages to use her challenge to sexism in order to reinforce the challenge to western domination suggesting that there is "no sweetness" in all hierarchies.

In African societies, men traditionally play double roles; they are both oppressed and oppressors. They fight the oppression of the colonizer or the repressive post-independence regimes while simultaneously, practicing oppression over females. This applies to the ordinary male, be it a father, brother or husband, who seeks control over his females, or a writer or critic who belittles the work of his fellow female writers and relegates it to an inferior position.

In "The African Woman Today" Aidoo attempts to explain the reasons that lead to the marginalization and disempowerment of African women at the present finding that the inherent social traditions, among other reasons, are responsible for that:

African traditional societies seemed to have been at odds with themselves as to exactly what to do with women. For although some of them appeared to doubt gender and biology as bases for judging women, in the end, they all used gender and biology to judge women's capabilities.

232).

She believes that these indigenous societal patterns were further intensified by the colonial heritage that led to further oppressing and disempowering of women of all social classes. It can be safely assumed that this effect appears more clearly in the higher social classes which assimilate the ideological influence of the colonizer and internalize its attitudes towards women. Whether men are aware of this or not is not the question here; the real issue is that females, especially writers, are challenging both hierarchies, colonial and patriarchal.

Another set of hierarchy that Aidoo challenges is that of the self-righteous western feminists whose dialectic about third world women contributes to colonial discourse by justifying the colonizer's control. The emergence of Western feminism during the 1800 s coincided with colonial expansion and provided it with further justifications for its control: brining equality between males and females in colonized countries. Like Estelle Freedman, Aidoo believes that "these feminists employed images of victimized foreign women and brutish foreign men to justify their activism as part of the 'white woman's burden'" (Freedman, 98). Freedman points out that the way western feminism handled the issue of non-western women is in itself racist.

Generally speaking, Aidoo's fiction deals with the role of African woman in post-colonial Ghanaian society. In the process, she challenges a wide range of hierarchies, from the oppression of the colonizer and the stereotypical images about Africans the west propagates, to the 
nationalist leaders who lure their people into thinking they are true heroes working against oppression while, in reality, they use the idea of nationalism to further oppress their people and promote their personal goals. Another set of hierarchy that Aidoo works against is the patriarchal dominance so deeply rooted in African societies whether on the individual or professional levels; that is within the family or in the public realms. Aidoo laments the fact that African male writers and critics misrepresent African women and critics belittle their works. To her, some of the critical studies written by men about the work of African women writers are "expressions of prejudice and lack of clarity" (Aidoo 1998, 20). She names Oladele Taiwo's Female Novelists of Modern Africa as an example describing the author as "self-righteous" and "insensitive" critic who

treats the female authors of those novels... as thought they were his co-wives, to whom he dishes out his whimsical favors. $\mathrm{He}$ constantly remarks on their intelligence or storytelling capabilities in the best "dancing dog" tradition or as if the writers were a bunch of precocious six year olds who had demonstrated some special abilities to the head teacher. (21)

Aidoo articulates the African women writer's dilemma as a part of women's life generally:

Women writers are just receiving the writer's version of the general neglect and disregard that women in the larger society receive... You know that the assessment of a writer's work is in the hands of critics and it is the critic's who put people on the pedestals or sweep them under the carpet, or put them in a cupboard, lock the door and throw the key away. I feel that, wittingly or unwittingly, people may be doing this to African women writers. (Qtd. in James, 12)

In addition to unfair African male critics, Aidoo complains, from her own personal experience as a lecturer of African literature in western universities, about the stereotypical ideas western people hold about Africans generally and women in particular:

Our colleagues in English departments left us in no doubt that they did not think that what we had come all the way from another continent to offer was literature. Never mind that they never bothered to read a single African novel, volume of short stories, or a collection of poetry. As far as they were concerned, our courses were only needed so that those students who wanted to take them to fulfill the requirement to study something on "diversity" or "multiculturalism”-read

"blacks" and "women" -could do so. (Aido 1998, 15). Emphasis by Aidoo

Added to this condescension on the part of Western professors was arrogance of white feminists, exemplified in those working in women's studies departments who "behaved, consciously or unconsciously, as though we (African women writers and 
professors) should have felt and appeared grateful that African women's literature was considered worthy of being offered alongside the works of major Western women writers" (Aidoo 1998, 15). Emphasis by Aidoo.

Aidoo believes that African professors were even expected to pay for the privilege of being allowed to "teach on the same campuses as them" (16) in the forms of "slavish agreement with them on relevant current discourses, including issues relating to Africa, Africans, and African women, or with our silence" (16). She laments that "from an early age, young people in the west are bombarded with images of Africa and Africans that can only be described as wicked and defamatory." (16) Therefore, even Western students, she believes, dealt with African professors with condescension. She narrates an instance in which she was once reported to the head of the department when she refused to agree with a student that one of the female characters in an African novel sounded "mythical" because she was more independent than a "real African woman can possibly be" (16). (My italics)

Through her work, Aidoo seeks to subvert the stereotypical images about African women propagated in the west and elsewhere by celebrating strong independent females who manage to survive all sorts of hierarchies. Here's how she expresses this in an interview with Adeola James:

If I write about strong women, it means that I see them around. People have always assumed that to be feminine is to be silly and to be sweet. But I disagree. I hope that in being a woman writer, I

have been faithful to the image of women as I see them around, strong women, women who are viable in their own right. (Qtd. in James, 12)

Her collection of short stories No Sweetness Here (1970) hosts such females belonging to all segments of postcolonial Ghanaian society. Aidoo depicts the different layers and manifestations of the oppression of African women showing political, economic and cultural aspects of the problem while also clearly demonstrating that many of these problems are not exclusively faced by women but rather part of the larger societal problems of post-independence Ghanaian society. The role of women is clear even when the protagonists of the stories are not females. Women's role in society, she seems to be saying, might be invisible but it is always influential.

In "Everything Counts", the first story, Aidoo introduces Sissie a young female professor of economics who gets her degree in Europe after independence and willingly comes back to Ghana to serve her country. All the time, whether in Europe or back home, she tries to define herself in relation to the national liberation struggle or the "revolution". She attempts to figure out her role in society and to define her status as an influential member in that society as well as negotiate her status as an African woman dealing with issues of western ideals of feminine beauty.

Like her male colleagues in Europe, she is concerned with figuring out the problems that prevent the real liberation of her people. While they 
believe that aspects of cultural imperialism such as the wearing of wigs by African women to look "European" are dangerous, Sissie renounces this influence as a trivial one and addresses the more serious ones. "Listen, my brothers, if we honestly tackled the problems facing us we wouldn't have the time to worry about such trifles (6)", she tells them. She finds that the most destructive influence of imperialism is the economic and material ones. To her, these are the real enemies of the liberation of Ghana and Africa in general. She defines the problems that occur on the economic level as resulting from what she calls "second-rate experts giving first-class dangerous advice. Or expressing uselessly fifth-rate opinions. Second-hand machinery from someone else's junkyard" (1) or giving a lecture on "automation as the newest weapon of the industrially developed countries use against the wretched ones of the earth."(5).

Significantly, while these male comrades stay in Europe after getting their degrees, as they "found the thought of returning home frightening", Sissie takes the decision to go back to teach and she starts to analyze and criticize the colonial heritage from within. She is preoccupied with her status as an African woman dealing with issues of western ideals of feminism. The wearing of wigs by most African women and their feverish attempts to lighten up their skin color to follow European standards of female beautypractices she previously found trivial while in Europe- start to get on her nerves - Everywhere she goes, she finds women wearing wigs: in the university, and outside "from the air-stewardesses to the grade-three typists in the offices, every girl simply wore a wig" (3). By the end of the

story, Sissie realizes she has underestimated the ideological influence of imperialism, especially on African bourgeoisie class. She comes to believe that renouncing all that is African for all that is European is as dangerous and destructive of nation building as economic imperialism since it undermines African ideology and threatens the ability of Africans' growth and liberation on their own. Back home, she can see clearly through what she and her "brothers" had argued about in England:

"But Sissie, look here, we see what you mean. Except that is not the real point we are getting at. Traditionally, women from your area might have their hair long. However, you've still got to admit that there is an element in this wig-wearing that is totally foreign. Unhealthy."(Aidoo,5-6).

Sissie sees through her situation and agrees that there is something "foreign" and "unhealthy" about her wearing a wig, and that it is not just a hair cover or "a turban" as she had argued before. It is a deviation from being an authentic African woman; it is some sort of colonial contamination, and it counts, just like material usurpation, hence the title of the story "Everything counts".

Aidoo seems to be saying that it takes more than understanding the fundamental economic and material problems of Ghanaian society to be able to achieve liberation. She puts into fiction what Frantz Fannon theorizes about in Black Skins, White Masks believing that "White civilization and European culture have imposed an existential deviation on 
the black man" (xviii). The idea of a double-consciousness for the colonized is another way that European colonization oppresses people. It makes them feel torn between the cultures that they are being "fed" as superior, and the culture of their people. In "Western culture: The cause of Ghana's decadent society" Kwame Osei believes that western culture " creates a dependency culture which is very dangerous but above all develops in the psyche an enslaved mentality that gives ammunition to those who see us as less than worthy."( modernghana.com) Sissie, realizes that and sticks to the authentic culture of her own people. At the end of the story one cannot help comparing her to another Sissie, the heroine of Aidoo's novel Our Sister's Killjoy, who is comfortable in her own skin, and never attempts to look or behave otherwise or adapt in any way to please the white folk.

In "Other Versions", Aidoo represents another "version" of the consequences of colonialism and of the African encounter with the West, only it is an encounter by a male. Exposed to the dominant western culture, Kofi is able to look at his life back in Africa from another angle. Like most students chosen to study in the west, he is an exceptionally clever scholar who finds out more about himself and his own country while studying there. $\mathrm{He}$ is aware of the presence and status of other blacks, the African Americans all around him. His epiphany comes in a New York subway one night when he meets a black woman who somehow reminds him of his own mother and cannot resist the urge to help her by offering her money which she politely refuses. The incident brings to his mind another one that occurred many years earlier when he attempted to give his mother four pounds from his first pay as a student working during school vacation. His mother, in reaction to the grateful gesture, adamantly refused the money and expressed how proud of him she was:

I too am coming to something in this world. Who would have thought of it. I never slept to dream that I shall live to see a day like this. Now I too have got my own man who will take care of me..... Yes and after all this business, she did not take the silly money. (129)

She refused to take the money in a motherly self-denial tendency that he has always seen in her, but asked him to give his father four pounds from every pay he ever gets. This made him very upset; he wanted to reward her love, sacrifices and self-denial and to show gratitude for the significant role she played in his life but he ended up rewarding his father, who never sacrificed anything for him and had refused to pay for his education.

Patriarchal dominance deeply rooted in Ghanaian society prevents the mother to accept her son's gift of money; she instead forwards it to the male figure in the family in an act of self-denial and servility to her husband. Kofi fails to understand her motives until years later when he meets the black old cook Mrs. Hye after a dinner at his professor's house. This "American" "invisible" cook, like his mother, and like other African and African American women, asks for nothing and is satisfied by her "invisible" position in life. When he approaches the old woman in the subway and attempts to give her twelve 
dollars, a sum which "was as near to four pounds as you could get" (134) he is still driven by the same sentiment that he could not understand before. Aidoo seems to be saying that the status of black women, whether in Africa or in America, is the same despite the cultural differences. In condemning the patriarchal practices in Africa, she is also condemning the racial and economic inequality women suffer from even in the west.

Vincent O. Odamtten in "Sojourners in the Lands of Former Colonizers" rightly analyses Kofi's attitude saying:

Even as he advances up the educational ladder, Kofi is gnawed by the inequity of a matrilineal society's ideology subsumed by a system of patriarchal privilege compounded by the abuses of neocolonialism. The consequences of such a confluence, internalized and accepted as "normal", inhibit his mother's ability to accept the gift from her son, the fruits of her labor. (Odamtten, 255 in Challenging Hierarchies).

The journey Kofi and Sissie take into the land of the colonizer, then, helps them realize and analyze the truth about the relation between colonized and colonizer and better appreciate their "native" culture. Kofi comes to believe that his mere presence in the lands of the colonizer proves that the colonial experience is still present even after his country's independence. The colonizer has found other pretexts to manipulate and usurp its former subjects and keep them at the mercy of the imperialist economic and cultural and ideological power. As a recipient of business syndicate's scholarship that was in bad need of an "especially bright.... African" (Aidoo, 32), Koki finds himself tied to the colonial center in a more subtle way. He realizes that if he stays, he will always be used and marginalized in the west just like his own mother, being a woman in a patriarchal society and the African American women he meets in America are. He decides that the best gift he could offer to his mother is being true to himself by shunning the opportunistic road he is pursuing and going back home.

The third story "For whom things did not change" touches on the disillusionment of ordinary Ghanaian people in their government policies after independence. Aidoo continues to address the economic and social problems that plague the post-independence Ghanaian society. As the title suggests, "things did not change" for the ordinary people as the changes that took place after independence were to serve the interests of the big people, the ruling class and educated officials. The title works on two levels describing at once the unconventional African doctor and the steward-cook who works for him and epitomizing the postindependence dilemma in which both the poor and educated Africans live. More significantly it describes, in a negative way, those for whom things did change after independence, namely those who hold important government posts or "the big men". As understood from the story, they have turned into "white-like" masters themselves, adopting the life-style of the white colonizer and enjoying the privileges of government positions and, 
above all, oppressing their poor and ignorant fellow Africans the same way the colonizer used to do.

Aidoo represents the interaction between the top and bottom segments of post-independence Ghanaian society. She introduces young Dr. Kobina as a deviation from the above image of an educated African and allows him to interact with Zirigu and his wife, the caretaker of a government rest house. The story starts with a conversation between Zirigu and his wife Situ. The rest house they take care of used to host white people during colonial time and African government officials after independence. To them, this master, Dr. Kobina, is different from all those whom they worked for before. He does not act like other educated black people who behave in the manner of white masters. He treats them decently as equals, refuses to eat "master's chops" and eats "things of the earth" just like Zirigu and his family.

In the course of the conversation the cultural influence of colonialism is revealed through Situ's criticism of other black clients, the "big masters" of the city who seduce young girls for money. She also curses the mothers and fathers of such girls for allowing them to be prostitutes and thanks God she has only sons. Situ, a strong, hard working woman, comes to the bottom of the problem- the corruption of government official which leads to the corruption of less privileged social classesjust like Dr. Kobina does on one of the conversations with Zirigu. Kobina recounts the tale of a large yam that his grandmother found in her field and started to cut for him as a child only to find it rotten layer after layer. Finally, she gouges out the head of the yam and finds it also rotten. The young man, Kobina, draws from the childhood parable a significance for the corrupt social context of modern Ghana; it is rotten from head to toe:

What was it that ate it (the yam) up so completely? And yet, here I go again, old yam has to rot in order that new yam can grow. Where is the earth? Who is going to do the planting? Certainly not us - too full with drink, eyes clouded in smoke and heads full of women. (Aidoo 22)

Zirigu, who at first seems to comply with the status quo and accept his destiny as a servant and a slave, even to his fellow Africans, shows his indignation and disillusionment about the conditions of his life. He allows himself to question the whole value of independence when he asks Kobina "My young Master, what does "independence" mean?" (27) The question is both heart-breaking and hopeful. All he has ever hoped for was getting some electric lights and "water-faucets and a toilet seat" when the rest house was renovated. He has kept the place well for ten years, first for white people and then for African officials, working as a keeper, a steward, and a cook and he naively thought it would not cost much to put on those simple life-changing things for him. $\mathrm{He}$ is very bitter when he finds out that all the place was redone, except his lavatory: Ah my Master, I did not know I wanted these things so much until I knew I was not going to get them. . . . My own people who are big men do not think I should use these good things they use. Something went out of me then 


\begin{tabular}{|c|c|}
\hline 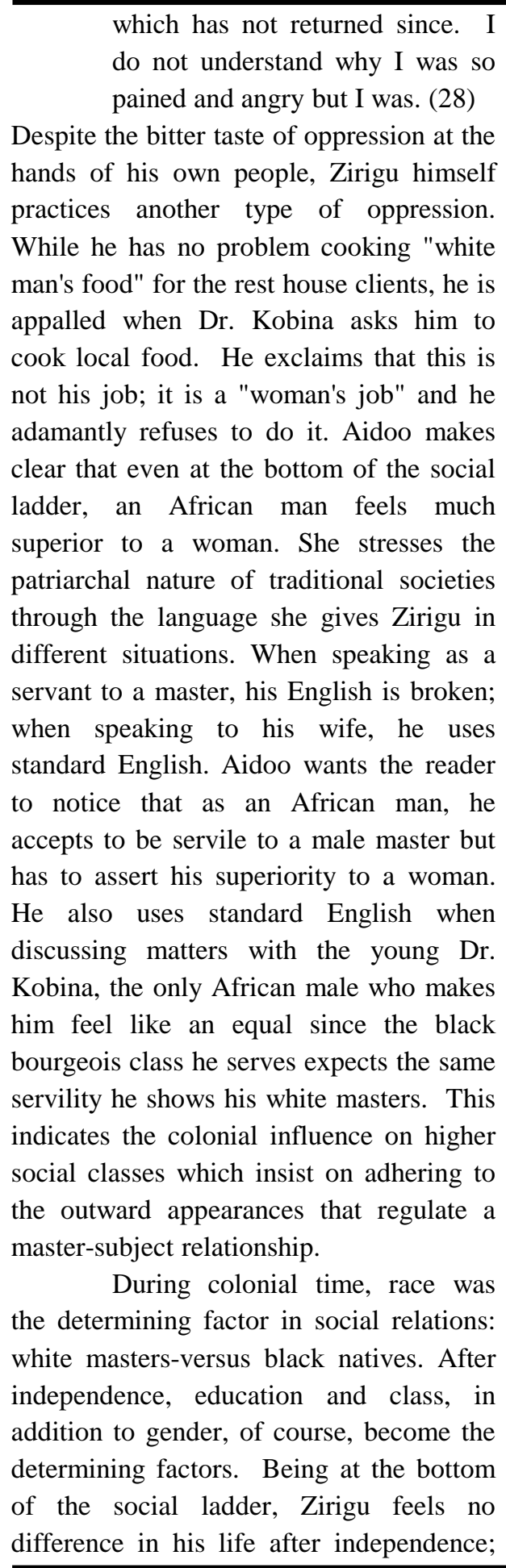 & $\begin{array}{l}\text { his white masters are replaced by black } \\
\text { educated people so "things did not } \\
\text { change"; they even got worse since he is } \\
\text { oppressed by his own people. The story is } \\
\text { an indication of failure of independence to } \\
\text { bring improvement to the majority of } \\
\text { people's lives and the influence of } \\
\text { colonialization on all segments of society. } \\
\text { "No Sweetness Here", the title piece, } \\
\text { tackles in more detail patriarchal } \\
\text { dominance and the marginalized status of } \\
\text { women in traditional African societies and } \\
\text { touches on the theme discussed above. It } \\
\text { is narrated from the point of view of } \\
\text { Chicha, which is the local pronunciation of } \\
\text { "teacher" in Fanti, Aidoo's first language. } \\
\text { That she is not given a personal name } \\
\text { suggests that her role depends on her } \\
\text { status as an educated westernized person } \\
\text { working in a traditional Fanti village and } \\
\text { therefore different from the rest of the } \\
\text { characters. As a school teacher, she relates } \\
\text { to Maami Ama, whose beautiful son } \\
\text { Kewsi is Chaicha's favorite pupil. As the } \\
\text { story opens, Chicha teases his mother that } \\
\text { she is going to kidnap him because he is } \\
\text { not only handsome but intelligent and } \\
\text { clever as well. The mother is both pleased } \\
\text { and concerned about the teacher's } \\
\text { comment since she already lives in fear of } \\
\text { losing her precious son to her unfair } \\
\text { husband. Although she is his first wife, a }\end{array}$ \\
\hline
\end{tabular}


her over the course of their ill-fated marriage. Shortly after this decision is made, Kwesi is found bitten by a smake, and dies the same night. After the funeral, Chicha finds Maami Ama alone in her hut, holding his schoolbooks and uniform in the agonized mourning of a woman who lost all she had in life.

Aidoo places Chicha in the context of a traditional small village as an outsider to be able to detect and comment on the marginalization and disempowerment of women in traditional African societies. Her point of view is projected against what the villagers think of Maami Ama and her struggle to get her freedom from her husband. According to traditions, Ama cannot just cut loose of marriage that simply even if she is abused by the negligence and mistreatment of her husband and his family. Chicha not only understands her situation but also admires her strength and courage and sympathizes with her while everyone else, including her own blame her for that bold decision of divorce. Even worse, they hold her responsible for the accidental death of her own son as a punishment for her straying away from the traditions of the patriarchal society and its marriage customs which give the man the right to do whatever he likes to his wives and expects them to do nothing about it.

Like Sissi in "Everything Counts", Chicha attempts to negotiate her own place and role within post-colonial Ghanaian society and comes to the same conclusion: the failure of national liberation to effect social change. The villagers praise her for the good job she does with the children, but deep down she is disillusioned as she could do nothing to prevent the catastrophic end of a promising child and his brave mother. To her, Kewisi represents hope of what independence should offer; he could have been a good man and his tragic death as a child stands for the disillusionment and failure of the independence to change people's lives.

Aidoo touches the same theme of male dominance and victimization of women in "A Gift from Somewhere" in which Abena Gyaawaa and her children are verbally and physically abused by her husband all the time. Unlike Mama Ama, she never thinks about divorce or taking any action to put an end to her misery. Everything changes in the family when she once interferes to rescue Nyamekye from his abusive father and receives a hit which gives her a permanent scar. Though she has other boys and girls, Nyamekye remains her favorite child, being her first to survive after losing three babies. The physical scar heals with time but the psychological wound remains to ruin the relationship between the husband on one hand, and Abina and the children on the other: "He is worse. He is angry all the time. He is angry with shame." (85). Abena changes too; she becomes emotionally detached: "But I do not even care. I have my little ones. And I am sure someone is wishing she were me. I have Nkyamekye and for this, I do not even know whom to thank." (85) Though she is not happy about how her husband treats her, she spoils her son and raises him to be a traditional male figure himself; he is the "gift from somewhere" the title refers to.

The indigenous societal patterns of patriarchal dominance we see in the previous stories are not the only form of oppression contemporary African women 
face; Aidoo also depicts in subsequent stories the effects of the colonial heritage on further oppressing and disempowering women of all social classes. It can be safely assumed that the higher in the social ladder a woman belongs, the stronger the colonial influence on her life is. since it is in these classes assimilate the ideological influence of the colonizer and internalize its attitudes towards women.

In "Certain Winds from the South", Aidoo discusses the aftermath of colonialism and the wide gap it caused between northern and southern Ghana. In "Male-ing Names in the Sun ", she stresses that the British used the already existing troubles between the Achanti and the Fanti tribes, belonging to north and south Ghana respectively, for their own benefit, thus further widening the gap between them:

Those were the 1920s. Oguaa was the big city of Fantis, who then congratulating themselves for having used the British to conquer Ashanti, their more aggressive relatives to the north, whom they were always in mortal fear of! The British had "pacified" Ashanti, looting Kumasi, the capital, especially of its legendary gold arts and finally exiling the king (90).

The British rule increased the enmity between north and south, neglecting the north and helping the south to be the "selfappointed, self-conscious fashion center of the Gold Coast while its people set about the business of Europeanizing themselves with panache"(90). The north and the rest of the country looked upon the south with "a mixture or derision and envy" (91). The north suffered abject poverty and unemployment while the south, having supported the British prospered economically. This is the background against which the events of the stories dealing with the north takes place.

"Certain Winds from the South" mainly discusses the effects of poverty on families and particularly the experience of women and children who are left behind by men who must seek work in the south to support their families. Mama Asana knows that her son in law Issa is leaving her daughter Hawa and their ten-day old baby Fuseni in her care to find work in the south, and is unable to face his wife with the news. She is both angry and terrified since the occasion brings to her memory another incident that happened twenty years before. It is the story of Asana's own husband who was a soldier fighting against the British in the south when she was pregnant with Hawa. When news came he was dead, Hawa was three days old and Asana went crazy with sadness. She was told she would get a huge sum of money if she went south and proved she was his wife but she never does, "It was him I wanted, not his body turned into gold" (55) she tells her daughter. Twenty years later, her son in- law has to go south to work because he cannot afford to feed his wife in maternity.

Simple as she is, Asana is full of fury at the government which sends soldiers during colonial time to "fight other people's wars" (55) and still finds excuses for lack of food and cloth for its citizens even after independence:

Those people, the government's people, who come and go tell us trade is bad now, and once again there is no tinned fish and no 
cloth. But this time they say, this is because our children are going to get them in abundance one day. (55)

The story ends as Asana continues to toil to feed her daughter and her grandchild. She is like many disempowered women in Aidoo's stories who have the will to survive despite their poverty and the crushing saturations of being abandoned by men. To use Mphahlele's words, she "simply gets up on her feet and asserts not her importance in relation to the male, but her motherhood. (Mphahlele, $\mathrm{xx}$ )

Aidoo, however, does not place the blame on the Issa for leaving. Rather, she understands the plight of men who have no choice but to leave their families behind looking for work in the south. The blame goes to post- independence governments and nationalist leaders who do nothing to improve the quality of life for their people and help them realize their essential needs. Like her creator, Asana realizes Issa is not neglecting his family; he is desperate as he tries to explain his situation: "what will be the use in my staying here and watching them starve?" (p.50).The drastic conditions in the north give him no choice. Likewise, Mama Anasa and her daughter have no choice but to survive with a certain stoic acceptance, leaving us to wonder about the strength and resilience of African women.

Another example of the strength and resilience of African women is to be seen in "The Message" in which another old poor villager from the north is depicted doing whatever it takes to help her granddaughter for whom she feels responsible. Once Nana Amfoa, gets "the message" that her only granddaughter Esi is "opened up" to deliver her baby, she presumes her dead and decides to travel to Cape Coast to see for herself. Nana Amfoa has lost all her children and Esi is the only daughter of her son who, Like Asana's husband, died in the war (43). The war has taken all the men in the family, leaving grandmother to care for granddaughter who is "the end of her root" (43).

The message terrifies Nana Amfoa and the journey to Cape Coast is intimidating since she has never set foot outside her village. The whole village sympathizes with her, believing that Esi must be dead and she must claim her body at the hospital. A young driver from the village insists on taking her to the hospital himself because he knows that in the city no one shows respect for the old and no one will help her. The story stresses traditional morals of caring for others and helping one's neighbors, qualities which are fading out in the city.

After a long tiring trip, Nana Amfoa fails to find Esi, since the hospital uses only European names for patients and no one can help her because she does not know Esi's European name. It turns out that the grandchild has a cesarean to deliver her identical twins and that everything is fine with her and the babies. The grandmother is happy that her last "pot is not broken" (46).

The miserable time the old poor Amfoa goes through until she finds her granddaughter by mere chance is Aidoo's way of mocking the naming system adopted during British rule and to comment on the many ways colonialism lead to the misery of people on all different levels. Even after independence 
Ghanaians had to dispense with their traditional names and adopt Christian ones if they wanted to have anything to do with the government. In "Male-ing Names in the Sun", Aidoo makes fun of the whole concept. She adopts the point of view of a British priest having a hard time to find a Christian name for a "native" child to be able to enroll in school:

The reverend had tried to be patient, but all this was taking too long, and getting too far. How could he explain the new system brought by the Europeans to them [the boy and his parents]? He knew that his people's naming system defined each individual clearly, with no ambiguities. However . . . he had to admit to himself, it was based on some ... eh. . . unfortunately primitive matrilineal notions. Whereas the European system of naming people against on singular male line was. . . eh. . . more ... sensible, Christian and civilized. (94)

As the quote suggests, the British priest himself is not convinced of the necessity to adopt Christian names for Ghanaians since traditional names are enough to identify a person; the only justification he comes up with is that Christian names sound more "civilized". To the child's parents and the majority of simple uneducated people, like the grandmother in "The Message", the system is not only confusing but also destructive of one's distinguished identity as an African. In giving up one's name, one also loses the whole identifying connotations it has and the traditional associations that go with it.
It is another way of westernizing people and effacing traditional concepts as it puts Africans in somebody else's mold, that of the colonizer. It is this child and many others like him who are fed the colonial culture and ideals and who later rule their country through corrupt postindependence governments. They turn into internal colonizers, oppressing their own people and usurping the country's resources to promote their positions, never caring for public benefit. Example of these would be "big men" are there in many of the stories; they represent the corruption that Dr. Kobina , Zirigu and Setu complain about in "For whom things did not change", they are the politicians who do not care for people suffering poverty and unemployment in "Certain winds from the south" and others who victimize women and use them as commodities in the following three stories. Auntie Araba of "Something to Talk About on the Way to the Funeral" suffers the same fate like Asana and Hawa and manages to survive on her own after being abandoned by the father of her child and later by her own son. Her story is narrated through the gossip of her nephew, Yaabba and her friend during Araba's funeral. Their conversation reveals not only memories about lovely aunt Araba, her beauty, talent in baking and the sweet scent of her bread but also severe criticism of the "big men", that is, the government officials who make use of everything and everyone for their benefit: "Oh as for our big men. Hmm. Let me shut my trouble seeking mouth up... you know indeed, these our big educated men, have never been up to much good "(115). The two women also gossip about aunt Araba's life 
as a young woman. She was sent as a girl to a relative's house to learn baking only to be sent home pregnant with the baby of her relative's husband, one of the "big men". When Ato, her son whom she raises on her own, grows up and becomes a "scholar", he seduces a young school girl, gets her pregnant and leaves her in the same manner his father had done to his mother. The narrator laments the fate of that promising girl, Mansa who was nearly killed by her parents and forced to leave school. The incident suggests that no change or development can be seen in society over the years. While Aunt Araba dies, after a life of suffering from abandonment and degradation in a corrupt male-dominated society, Mansa lives to face the same fate years to come. That the seducer is always an educated, westernized "big man" again suggests the weight of the colonial legacy; those men internalize the western morals and attitudes towards woman.

"In the Cutting of a Drink" and "Two Sisters", still play on the theme of sexually objectified females and stress the patriarchal nature of Ghanaian society and the colonial influence. The stories deal with different places, rural and urban as well as different segments of Ghanaian society. Aidoo also represents the daily lives of some of the elites to establish the reader's sense of shock at the discrepancy between the luxurious way they live and how ordinary people live. In these two stories, she criticizes a post-colonial moral, social dilemma; "big men" who seduce, abuse and sexualize young girls by money, cars, and high rank positions in society. Though the girls belong to different social classes, a poor uneducated villager in the first, and a middle class sister in the second, the dilemma is the same as it was for Aunt Araba and Mansa; they are all abused by the big men. The stories also address social ills that came with independence such as moral deterioration and progress through connection or proximity instead of meritocracy.

In "In the cutting of a drink" Mansa runs away from home and her brother is sent to Accra to find her with the help of a cousin of his who lives and works there. As a villager, he is amazed at everything he sees in the city. Through his eyes, we observe the cultural changes that took place in the city: the number of cars in the streets, the street lights, women living with men they are not married to, women drinking bear with men and others working as prostitutes. Above all, he is astonished at how men and women related in the city and how his cousin treated his girlfriend: "A woman prepares a meal for a man and eats it with him. Yes they do so often" (33). When they went out to have a drink he "sat with [his] mouth open and watched the daughter of a woman cut beer like a man" (34). He sits in the bar watching "bad women of the city" only to find out at the end that his sister Mansa is one of these women who entertain men for a drink and cigarettes.

The story comes in the form of a detailed narration of what happens to him from the moment he sits foot in the city to the moment he accidently sees his sister in a bar; the title refers to the effects of white men on the people of the city as observed by this villager who finds people talking in the language of the white man, dressed like a white man and dancing like a white 
man. Aidoo seems to be saying that her people are only catching the outside appearance and behavior of colonizers and mourns the loss of moral traditions. The narration ends sadly with Mansa's words for her "Brother, cut me a drink. Any work is work... is work...is work" (37). Back to the village, he asks his mother, aunt, and other sister not to weep for Mansa. She accepts prostitution as a "job" and her brother cannot do anything about it.

Aidoo is sharp in her criticism of how the colonizer has destroyed family traditions and trapped the natives into the kind of life they now live in the city. Mansa, she seems to be saying, is the victim of ignorance, poverty, and patriarchy but above all she is destroyed by the moral and social changes that afflicted Ghanaian society after independence. In this she is not different from the city girls Aidoo introduces in "Two Sisters": Mercy and Connie. Mercy is angry and dissatisfied with her lot in life; she does not like being a typist as she tells her older sister Connie: "I am sick of everything. The office, living with you and your husband. I want a husband of my own, children. I want... I want. (91). However, she refuses a young suitor who loves her only because he is a taxi driver, not a rich scholar as she aspires. She uses her body to acquire money and power taking a powerful, rich politician who is old enough to be her grandfather as a lover. When he loses his position as a parliament member, she simply replaces him by another "big man". Her sister is appalled when she knows that but mercy would not listen to her advice.

Though Connie appears to be the opposite of the rebellious over- ambitious
Mercy, she is also seduced by money, accepting an expensive present from her sister's lover, thus demonstrating the hypocritical nature of the morality which she espouses as it disappears in the face of material gain. On a different level Connie also suffers from men, that is, the infidelity of her husband during her pregnancy and she is forced to accept it silently in fear of losing him. Aidoo, however, does not necessarily condemn either of these women but rather demonstrates the corruption of Ghanaian society and the consumerist tendencies of the rising middle class.

Perhaps the harshest critique and the most exemplary of the disillusionment of the post-independence period is the critique of the politicians, the national bourgeoisie of Ghana. They offer government estates and expensive gifts bought with national money for their numerous mistresses while the majority of people in the country must struggle to survive. This corruption, however, does not arise simply as a result of the corruption of individual politicians but rather, it is a wider systemic problem as can be seen in Aidoo's depiction of the military coup which overthrows Mercy's lover and his government. Despite Connie's hope that the military will now "clean... up the country of all that dirt," (100) nothing changes. Mercy shows up later with a new lover, the new military leader of the country. It is impossible to tell the difference between the new and old leaders; like Mercy's shoes, no one can tell if "those are the old pair which were new a couple of months ago? Or are they the newest pair?" (101). 
Throughout the stories, Aidoo juxtaposes her critique of the elites to the emphasis she places on the strength of her characters who struggle to survive and overcome the obstacles that pervade the society. Forms of oppression that are represented in the stories are not exclusive to women. Men also do suffer from poverty, ignorance and unemployment. They are in this sense both victims and victimizers. Aidoo skillfully merges her challenge to sexism with her challenge to western domination in a way that one challenge reinforces the other.

All in all, the stories in No Sweetness Here are a manifesto of challenge against all hierarchies which are of an overlapping and complex nature: imperial hegemony and the legacy of colonialism that permeate the country even after independence, domination of women in all its forms whether traditional or colonially inspired and corruption and greed of repressive and illegitimate neo-colonial governments.

\section{Works Cited}

Aidoo, A. (1992). "The African Woman Today." Dissent (Summer): 319-325. ---. (1995) No Sweetness Here and

Other Stories. New York: The Feminist press.

---------. "Literature, Feminism, and the African Woman Today". Challenging Hierarchies, (15-36). (1998). "Male-ing Names in the Sun". "Literature, Feminism, and the African Woman Today". Challenging Hierarchies (87-96)

Ashcroft, Bill. (2001). Post-Colonial

Transformation. London:

Routledge.
Odamttenm, Vincent O. (1998).

"Sojourners in the Lands of Former Colonizers". In Challenging Hierarchies. Issues and Themes in Colonial and Postcolonial African Literature. New York: Peter Lang Publishing. (87-96)

Freedman, Estelle. (2002). No Turning Back: The History of Feminism and the Future of Women. New York: Random House.

James, Adeola, ed. (1991). (In Their Own Voices: African Women Writers Talk. London: James Currey.

Luis, William. (1981) ( "Re-Writing History: Cesar Leante's Llos Guerillos Negros". Journal of Caribbean Studies II. Mark Hoffiman. Evanston: Indiana University. (250-65).

Mphahlele, Ezekiel. (1971). "Introduction." In Ama Ata Aidoo. No Sweetness Here. Garden City, Ny: Doubleday.

Mugo, Micere Githae. (1994). My Mother's Poem and Other Songs: Songs and Poems. Nairobi: East African Educational Publishers.

Osei,

Kwame.

https://www.modernghana.com/news /297270/1/western-culture-the-causeof-ghanas-decadent-socie.html

Podis, Leonard A. and Yakugu Saaka, Eds. (1998) Challenging Hierarchies. Issues and Themes in Colonial and Postcolonial African Literature. New York: Peter Lang Publishing. 